Kádár, Judit. "Petneki, Katalin and Petrich, Kató. 2019. Gyermekvonat Angliába. Egy budai kislány levelei (19201921) ('A Children's Train to England. Letters of a Little Girl from Buda, 1920-1921'). Budapest: Európa Kiadó.

287 pp. illus." Hungarian Cultural Studies. e-Journal of the American Hungarian Educators Association, Volume 14 (2021) DOI: 10.5195/ahea.2021.447

\title{
Petneki, Katalin and Petrich, Kató. 2019. Gyermekvonat Angliába. Egy budai kislány levelei (1920-1921) ('A Children's Train to England. Letters of a Little Girl from Buda, 1920-1921'). Budapest: Európa Kiadó. 287 pp. illus.
}

\author{
Reviewed by Judit Kádár, Eötvös Loránd University, kadar.judit@sek.elte.hu
}

The book titled Gyermekvonat Angliába. Egy budai kislány levelei (1920-1921) ['A Children's Train to England. Letters of a Little Girl from Buda, 1920-1921'] is unique in that it consists of two kinds of documents or primary sources: a short diary and forty letters written by an adolescent girl, Katalin/Kató Petrich (1908-1987), who was only twelve years old when she wrote them. At that time, Kató was living in foster care in Bridgwater, in South West England, as a Hungarian beneficiary of an international child-relief operation acting in the aftermath of World War I. The two manuscripts were published by Petrich's daughter, Katalin Petneki, an associate professor of German Linguistics by profession, who added to the manuscripts two introductory chapters, one on early interwar international child-rescue initiatives and another on the history of the Petrich family. In the subsequent chapters containing the text of Kató's diary and letters, Petneki also includes excerpts from the replies of the girl's parents and grandparents to her letters. In addition, she inserts further explanatory sections with headings, which she groups around some of the topics that Kató and her mother discuss in their letters; examples of these is Mrs. Petrich's complaints about a fuelwood shortage and her difficulties in finding a maid who does not demand too high wages.

Kató Petrich's diary consists of the child-author's reports on her travel, along with other children, on a military hospital train across Europe to the Dutch port-town of Vlissingen and about the children's stay in a quarantine transit-center in Sandwich, England. Her letters, by contrast, depict how she and six other Hungarian girls, who were also placed in Bridgwater, spent their time with foster parents in town. Because Kató's is the only surviving contemporaneous correspondence in Hungarian from the time of the post-World War I child rescue operation in the UK, her letters provide valuable insight into the modest conditions in which these Austria-Hungary-born children lived with their British host families at that time. The contribution of Kató's daughter makes the book even more enticing since her additions create a palimpsest-like text made up of three layers written on the top of one another. This text, in turn, sheds light on how the further generations of a middle-class Hungarian family of German descent presently living in Buda feel about what happened to one of the family members in the 1920s, and how this girl's memories have faded or been preserved over the following hundred years.

$(\mathrm{cc}) \mathrm{BY}$

ULIS D-Senke
New articles in this journal are licensed under a Creative Commons Attribution 4.0 International License.

This journal is published by the University Library System of the University of Pittsburgh as part of its D-Scribe Digital Publishing Program and is cosponsored by the University of Pittsburgh Press 
Kádár, Judit. "Petneki, Katalin and Petrich, Kató. 2019. Gyermekvonat Angliába. Egy budai kislány levelei (19201921) ('A Children's Train to England. Letters of a Little Girl from Buda, 1920-1921'). Budapest: Európa Kiadó. 287 pp. illus." Hungarian Cultural Studies. e-Journal of the American Hungarian Educators Association, Volume 14 (2021) DOI: 10.5195/ahea.2021.447

Petneki's first introductory chapter, which briefly summarizes the beginnings of the international humanitarian relief movement to help Hungarian children impoverished by the war, lacks some crucial information, probably owing to the fact that the author is not a professional historian. Since there is little source-material available regarding the post-World War I British child-rescue efforts, and often the very term of "children's train" is applied only to Jewish children's evacuation from German occupation just before or during World War II, Petneki's introductory mini-study focuses, instead, on Dutch and Hungarian child-rescue initiatives. Probably for this reason, this chapter fails to highlight the importance of the philanthropic activities of two British sisters, Eglantyne Jebb and Dorothy (Jebb) Buxton, who established the Save the Children Fund (SCF) in 1919 in London. Initially, this pacifist organization funded by citizens of a victorious nation aimed to relieve the effects of child hunger in defeated enemy countries, namely Austria-Hungary and Germany. On the part of the British, this gesture of exceptional humanitarianism was due to the SCF, which, starting from August 1920, helped 465 Hungarian children, including Kató, to spend an almost entire year in the United Kingdom.

In the decade between 1920 and 1930 more than 60,000 Hungarian children were sent on long-stay rehabilitation-vacations to European countries and mainly to the Netherlands and Belgium. Curiously, throughout this decade no more such "rescue trains" left for the UK. The reason for the suspension of children's reception and stay in the UK was and remains unclear, but some of the difficulties that might have discouraged British host families may be inferred from Kató's correspondence. One plausible explanation for the termination or suspension of this type of British child-support, which was based on private or individual accommodation, may be that the host families and the sending families had different expectations regarding the nature of the assistance provided to the children. Presumably, most of the British host-families participated in the relief actions as members of a church organization. Being religious but not necessarily wealthy people, they tried to help those in need, saving innocent children from undeserved starvation. Yet, contrary to their belief, many of the children they hosted came from middle-class families, and though these youngsters were certainly disadvantaged at the time, they did not suffer from true, physical hunger as the host families might have imagined. The years after the loss of the war were marked by the spread of corruption so that, in fact, many of the Hungarian guest children were selected for these hunger-relief operations owing to the network of contacts of their parents. There were also quite a few Hungarian middle-class families in precarious financial situation who used the post-World War I foreign aid to grant their children with the opportunity to learn a foreign language, which had previously been possible only by sending them to foreign schools for a year and paying precious tuition fees.

Because the Petrich family's fortune had grown quite substantially before the war, there was a significant socioeconomic status difference between Kató's real and foster parents. Kató's maternal grandfather, Henrik Jurány, was the Managing Director of Calderoni and Co., a quickly developing optical instruments and teaching aids manufacturing company in Austria-Hungary, with a showroom in the heart of Budapest's downtown. Her father, Gyula Petrich, worked as the Head of the School Equipment Department at the same enterprise. Although the firm lost a significant part of its market after the dissolution of the Monarchy in 1918, it could still allow for a relatively high standard of living for the young girl's family. In contrast, Kató's foster father, Mr. Cockerell, was the owner of a small-town grocery store that also delivered vegetables and sweets to other shops, and compared to the Petrichs, the British family lived in modest circumstances. Therefore, when Kató first saw her future home in Bridgwater, she remarked in a 
Kádár, Judit. "Petneki, Katalin and Petrich, Kató. 2019. Gyermekvonat Angliába. Egy budai kislány levelei (19201921) ('A Children's Train to England. Letters of a Little Girl from Buda, 1920-1921'). Budapest: Európa Kiadó. 287 pp. illus." Hungarian Cultural Studies. e-Journal of the American Hungarian Educators Association, Volume 14 (2021) DOI: 10.5195/ahea.2021.447

letter to her family, with a little disappointment, that "Öt ici-pici szobájuk van" ['They have five itty-bitty rooms']; and she added that "én jobb, úribb családra számítottam" ['I was expecting a better, higher class family'] (83-84).

For their part, the Cockerells, who were members of the Bridgwater Baptist Church, were probably expecting to host a poorer child, and Kató's attitude toward culture and her constant need for cultural activities, which she had gotten used to in her bourgeois family, might have found them unprepared. However, the family, which housed an alien child considering that one of their sons was killed in France in the war, made great efforts to meet their foster daughter's cultural needs. After realizing how skillfully she could draw, they enrolled her in a drawingschool; indeed, years later, she graduated from the College of Fine Arts in Budapest and earned her living as a drawing teacher. Since the Cockerells only had a harmonium, Kató, who at such a young age was already a Richard Wagner fan, was allowed to regularly visit a wealthier family to practice playing on their piano. The well-mannered girl and her foster parents soon developed a good relationship, yet her correspondence reveals that some other Hungarian guest-children had to move from one family to another during their stay in the UK, probably at least partly because of the initial unfair selection of the children chosen. However, it is also possible that the reception of Hungarian children in the UK stopped as of 1921 because Eglantyne Jebb became determined to send aid to starving children in Russia, where following the civil war there was a greater danger of death.

Kató was sent to the UK by her father, Gyula Petrich, not only to learn English, but because he wanted to spare her the miserable times of greed and immorality which he foresaw for postwar Hungary. Looking back on that period from the vantage point of the twenty-first century, Petneki contends that the Hungarian middle class eagerly supported Horthy in the hope of consolidation and because of his anti-communist leadership. However, there is good reason to believe that the Petrichs were pro-Habsburg monarchists, as their son, who was born three days before Charles IV was crowned King of Hungary, was named Károly, after the Monarch, and Kató's maternal grandmother proudly participated in a famous ball in January 1921, where two high-ranking members of the House of Habsburg also showed up. Therefore, the failure of Charles IV's attempt to return to the throne may have disappointed the family, including Kató, who read about these events in Bridgwater in an English-language newspaper. At that time, Petrich, who tried to immerse himself in German culture, presumably under the influence of his father-in-law, was a member of the Singing Choir of the Social Association of Germans living in Hungary, the Eintracht ('Unity'). Petneki probably has no knowledge that her great grandfather's choir leader, Károly Schleif, whom Petrich had asked to be his daughter's godfather, was a member of a Masonic lodge in Buda (44). (Schleif's name is listed in Gyula Csápori's book, entitled A szabadkömüvesség elleni szövetkezet kézikönyve és a magyarországi szabadkömüvesek névsora ['The Handbook of the Alliance against Freemasonry and the List of Freemasons in Hungary']). Although Petrich may not have been a Freemason himself, his friendship with Schleif suggests that the rise to power of Horthy, who banned the Masonic lodges in May 1920, only two and a half months after his election as Governor, was not necessarily a desirable event for him.

There are other indications that, unlike his father-in-law, Petrich may not have been a Horthy supporter. Petneki describes the history of the family just until Kató's return, but it can be found in the Minutes of the Council of Ministers that in 1926 the girl's maternal grandfather, Henrik Jurány, was awarded the title of Hungarian Royal Commercial Counselor, which proves 
Kádár, Judit. "Petneki, Katalin and Petrich, Kató. 2019. Gyermekvonat Angliába. Egy budai kislány levelei (19201921) ('A Children's Train to England. Letters of a Little Girl from Buda, 1920-1921'). Budapest: Európa Kiadó. 287 pp. illus." Hungarian Cultural Studies. e-Journal of the American Hungarian Educators Association, Volume 14 (2021) DOI: 10.5195/ahea.2021.447

that he entered the post-war economic elite. In those years Kató's father founded an independent teaching-aids manufacturing company, and his breakup with his father-in-law's firm, which was thriving despite considerable market loss, suggests that Petrich may have had difficulties in integrating into the Horthy system. His own business presumably did not prove successful, which can be inferred from the fact that following her graduation from college, Kató had to support herself and, indeed, she found it very difficult to find a job as a drawing teacher.

When Kató's daughter speaks of Horthy, she actually expresses her own sympathies, because it turns out from her accompanying text that she is only partially aware of the views of her ancestors, who mention the Governor's name many times in their letters without ever making any comments about him. However, it can be concluded from Petneki's book that there has been one common view that all generations of this middle-class family shared. This was Horthy's vision of irredentism and hope for the recovery of the lost land, which pervaded even the thinking and writings of their twelve-year-old daughter. Apart from writing only a brief sketch of Kató's adult life, Petneki has also not published the letters of Kató's parents in their entirety either, omitting some parts that she considers unimportant. Still, realizing the richness of the materials included in the book as a whole and of the sources it introduces, its readers will appreciate this rare glimpse into the life of a Budapest middle-class family living in the challenging historical period following the First World War. 